\title{
Transhumant pastoralism, sustainable management of natural resources and endemic ruminant livestock in the sub-humid zone of West Africa
}

\author{
Augustine A. Ayantunde $\cdot$ Rainer Asse $\cdot$ Mohammed Y. Said • \\ Abdou Fall
}

Received: 10 September 2013/ Accepted: 11 January 2014/Published online: 17 January 2014

(C) Springer Science+Business Media Dordrecht 2014

\begin{abstract}
Transhumant pastoralism is one of the dominant livestock production systems in West Africa, and it is characterized by seasonal and cyclical movement of varying degrees between complementary ecological areas. The common pattern of transhumance is moving herds from areas with pasture and water scarcity such as the Sahelian zone to areas where the forage and water are found, often in the sub-humid zone. Whereas the transhumant herds from the Sahel are mainly Zebu breeds, endemic ruminant livestock (ERL) are the dominant breeds in sub-humid zone of West Africa because of their tolerance to tsetse-borne trypanosomosis disease. These livestock fulfill different functions in the livelihood of rural communities in the region. To identify potential areas of interventions for sustainable natural resource management to improve ERL productivity, a desk study that included spatial mapping was performed to review and document the existing knowledge on transhumance in West Africa. Additionally, group discussions were held to analyze the (actual or potential) effects of transhumant herds on natural resource management and ERL in the sub-humid zone. This study covered sub-humid zone in The Gambia, Guinea, Mali and Senegal. The key question we addressed in this study was as follows: What are the key trends and changes in transhumant pastoralism and how do these impact sustainable management of natural resources including endemic livestock? The results of the desk study and group discussions showed that there have been more southerly movements by transhumant pastoralists into the sub-humid zone over the past three decades and this has contributed to growing competition for grazing resources. The presence of transhumant herds in the sub-humid zone has a potential impact on management and conservation of ERL through crossbreeding with transhumant Zebu breeds from the Sahel but only study sites in Mali showed a high risk.
\end{abstract}

\footnotetext{
A. A. Ayantunde $(\bowtie) \cdot$ R. Asse $\cdot$ A. Fall

International Livestock Research Institute (ILRI), Bamako, Mali

e-mail: a.ayantunde@cgiar.org

M. Y. Said

International Livestock Research Institute (ILRI), Nairobi, Kenya
} 
Keywords Mobile pastoralism - Trypanotolerant livestock breed .

Sahelian breed $\cdot$ Rangeland $\cdot$ Sudano-Guinean zone

\section{Introduction}

\subsection{General background}

Endemic ruminant livestock (ERL) are the dominant breeds in the sub-humid zone of West Africa because of their tolerance to tsetse-borne trypanosomosis disease, which is a serious barrier to livestock production in the region (Zaibet et al. 2011). The endemic ruminant breeds in sub-humid zone are Ndama cattle, Djallonke sheep and West African Dwarf goat. These livestock fulfill different functions in the livelihood of rural communities in the region such as provision of meat, milk, draft power, manure, emergency cash reserve and other sociocultural functions. Although numbers of these breeds are still relatively high (FAO 2000; Boutrais 2007), their future is in jeopardy due to varied and complex threats, which can be broadly grouped into three primary categories: (1) destruction and degradation of ecosystems critical for ERL; (2) crossbreeding between ERL and transhumant Zebu breeds from the Sahel; and finally, (3) abandonment of ERL husbandry due to production and market constraints for other livelihood strategies.

To identify potential areas of interventions for sustainable natural resource management to improve ERL productivity, a desk study that included spatial mapping was performed to review and document the existing knowledge on transhumance in West Africa. Additionally, group discussions were held to analyze the (actual or potential) effects of transhumant herds on natural resource management and ERL in the sub-humid zone. The key question we addressed in this study was as follows: What are the key trends and changes in transhumant pastoralism and how do these impact sustainable management of natural resources including endemic livestock? Unlike most studies on transhumance pastoralism in West Africa (FAO 2001; Basset and Turner 2007; Boutrais 2007; SWAC/OECD 2007), which focused on pastoralists from the Sahel and their Zebu breeds, the focus of this study is on the transhumant practices (drivers, trends, advantages and associated problems) in the sub-humid zone of the region and the potential or actual impact on natural resource management including ERL. This study covered sub-humid zone in The Gambia, Guinea, Mali and Senegal that allowed for comparison of different countries.

\subsection{Transhumant pastoralism in West Africa}

Transhumant pastoralism is one of the dominant livestock production systems in West Africa, especially in Sahelian countries. Transhumance can be defined as a livestock production system characterized by seasonal and cyclical movement of varying degrees between complementary ecological areas (FAO 2001; SWAC/OECD 2007). In the recent past, the basic pattern of transhumance in West Africa has been a north-to-south migration in which pastoralists and their livestock transited from the more arid Sahelian region in the north to the more humid Sudano-Guinean regions in the south. This traditional north-tosouth seasonal migration covers hundreds of kilometers within or across national boundaries and lasts from 3 to 8 months. There is also the opposite migration to the pastoral zone in the north by the Sahelian pastoralists in the wet season to graze pastures in arid and 
semi-arid zones, which are often of high quality (Ayantunde et al. 2011). There is a general consensus that transhumant pastoralism is essential to maintaining ecological resilience of dryland ecosystems and ensuring livestock productivity. In West Africa, transhumant pastoralism is important for livestock productivity as it involves 70-90\% of the Sahel's cattle and 30-40 \% of small ruminants in West African Sahel (SWAC/OECD 2007).

Benefits of transhumance vary with different actors involved and social relations between the transhumant pastoralists and the host communities. For transhumant pastoralists, the benefits include herd productivity (more milk and improved herd reproductive performance), reduction in herd mortality that implies preservation of livestock assets of the pastoralists, low production cost involved and opportunities to build social relationships with the host communities. In terms of productivity of transhumant livestock systems, Breman and de Wit (1983) observed that transhumance in West African Sahel is more productive per hectare than sedentary livestock systems in regions with similar rainfall in Australia and USA (protein production in kg/ha/year: Australia-0.4; USA0.3-0.5; Transhumance in Sahel-0.6-3.2). However, if productivity is expressed per man hour, transhumance is much less productive than those sedentary livestock systems. For the host communities, the benefits of transhumance include deposition of manure on crop fields by transhumant herds and availability of milk from transhumant herds. Despite the benefits, there is potential for conflict between transhumant herders and crop farmers in the Sudano-Guinean zone especially through competition for grazing resources.

\section{Description of study sites and socioeconomic context}

\subsection{Agro-climatic characterization of study sites}

The agro-ecological and climatic zones in West Africa could be categorized into four which stretch from west to east and largely determine vegetation and weather patterns in the region: the Saharan (desert), the Sahelian (arid), the Sudanian (semi-arid) and the Guinean (sub-humid/humid) zones. The study sites were located in eastern Gambia, southern and southeastern Senegal, western and southern Mali, and central and southern Guinea, all in the sub-humid agro-ecological zone of West Africa (Fig. 1). This ecological zone occupies $16 \%$ of West Africa, with a rainfall of between 800 and 1,500 mm per annum and a crop-growing period of between 120 and 280 days (Fig. 2; Winrock 1992). The sub-humid zone can be further categorized into dry sub-humid (120-179 days) and wet sub-humid (180-279 days) (Winrock 1992). Rainfall is less variable than in arid and semi-arid zones, making crop production less risky and pasture potentially more productive. There are several endemic breeds and strains of livestock in this zone, the Ndama cattle being the most renowned. A wide variety of crops is grown in the sub-humid zone, including maize, rice, millet, sorghum, groundnuts and cowpeas. Farms are generally small though there is an increasing use of animal traction, especially for cotton production.

Twelve study sites were characterized based on rainfall and length of growing period (LGP) derived from 30 years of remotely sensed data (Vrieling et al. 2013). In terms of rainfall, the study site in Beyla, Guinea is the wettest of all the sites with average annual rainfall of $1,840 \mathrm{~mm}$ while Nianija and Niamina East in The Gambia have the lowest average rainfall of less than $800 \mathrm{~mm}$ (Fig. 1). The LGP varies from 132 days in Nianija in The Gambia to 230 days in Beyla in Guinea (Fig. 2). Growing season starts early in Guinea and Mali and followed later by Senegal and the Gambia (Fig. 3). The end of growing season is in November and December for most sites except for Tenghory that ends 

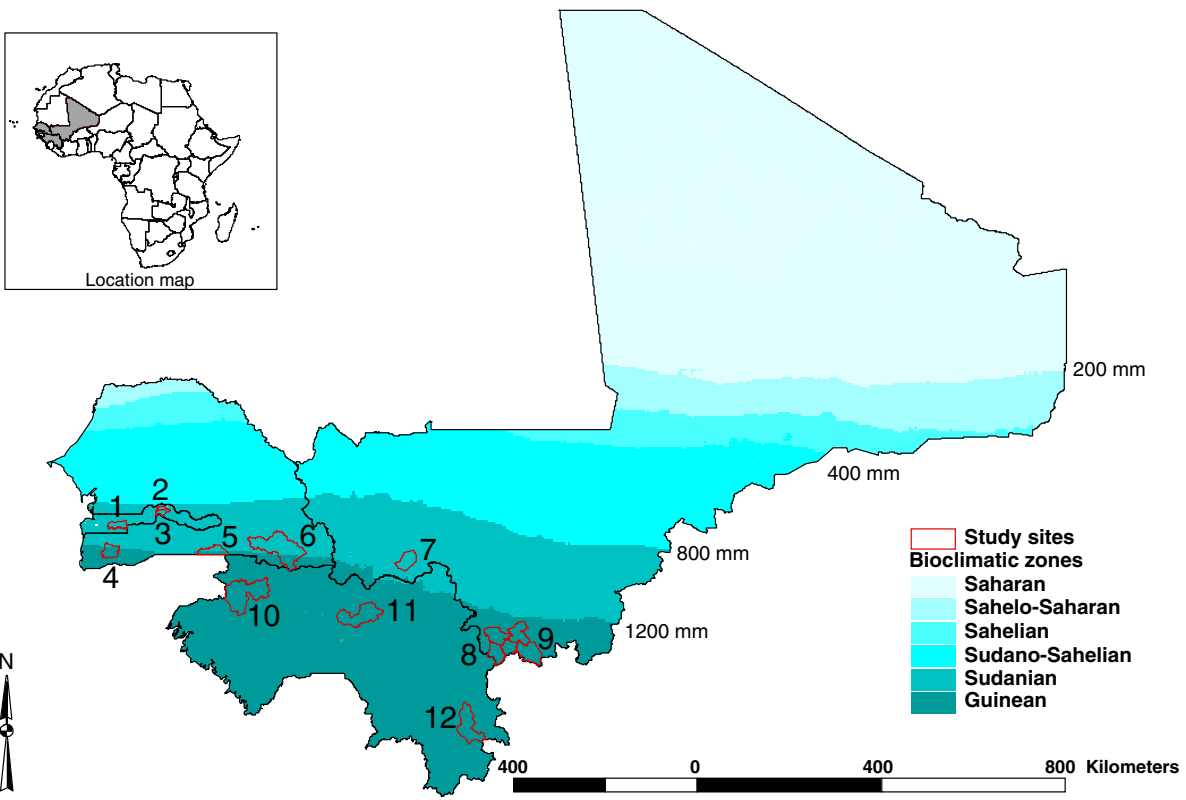

Fig. 1 Bioclimatic zones and rainfall gradient for the study sites in Gambia, Guinea, Mali and Senegal. The labels of sites are as follows: Gambia-(1) Kiang West, (2) Nianija, (3) Niamina West; Senegal-(4) Tenghory, (5) Wassadou, (6) Bandafasi; Mali-(7) Sagabary, (8) Madina Diassa, (9) Manankoro; Guinea(10) Gaoual, (11) Dinguiraye, (12) Beyla
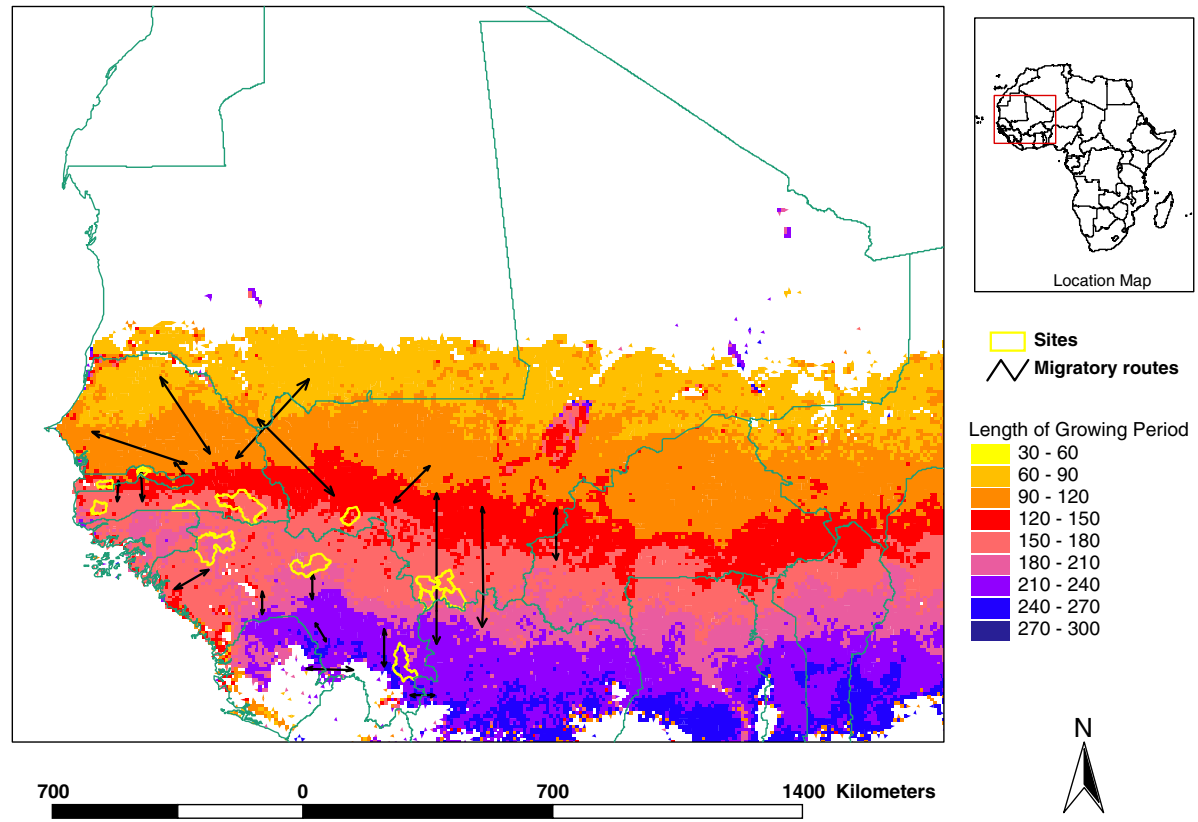

Fig. 2 Map showing the study sites, transhumant routes and length of growing period in Gambia, Guinea, Mali and Senegal 
in January (Fig. 4). All the project sites in Senegal and The Gambia, and Gaoual in Guinea are in lowland areas with elevation of less than $100 \mathrm{~m}$. The sites in Mali had elevation of about 300-500 m while Beyla and Dinguiraye in Guinea are highlands with elevation of more than $1,500 \mathrm{~m}$.

\subsection{Socioeconomic context}

Livestock ownership in the study sites is generally distributed in a highly skewed manner according to household wealth, especially for cattle with rich households owning 10-50 and the poor household categories with less than two cattle (Zaibet et al. 2011). Despite these differences, ruminants and in particular small ruminants are important asset for farmers of poor socioeconomic status.

The study sites are populated by two major ethnic groups: the Mande (Mandingo) and the Peulh (also called Fulani, Fulah and Fulbe). In addition to these two ethnic groups, there are other minority ethnic groups in the project sites such as Wollof in The Gambia and Senegal sites, Soussou in Beyla site in Guinea, and Minanka and Senofou in Mali southern sites. The Mande are generally in majority in most of the sites except for Guinea where Peulh are in majority. The Peulh are the dominant ethnic group in livestock husbandry in West Africa (Basset and Turner 2007), while the Mande are essentially farmers who may also raise endemic livestock on a smaller and less extensive scale. In most of the sites, the Peulh are generally sedentary and the majority does grow crops in addition to raising livestock, so they can be considered agro-pastoralists.

The ethno-linguistic landscape of West Africa is partly manifested in first-settler usufruct rights to natural and common pool resources such as land, vegetation and water. That is, access to natural resources depends to a great extent on membership in the ethnic group or clan, which can claim to have been the first to settle in an area. Usually, non-members or immigrants into a region must petition first-settlers for access to resources "belonging" to a region's first-settler ethnic groups or clans. Such settler-immigrant negotiation regarding access to natural resources is especially important in the context of transhumance since transhumant herders often traverse areas where they are not members of first-settler ethnic groups or clans. The long-term arrangements between settlers and immigrants (e.g., agriculturalists and transhumant pastoralists) are often the basis for norms and local conventions that frame access and rights to natural resources in a particular area.

\subsection{Endemic ruminant livestock production systems}

Livestock contribute significantly to livelihoods of rural populations in West Africa. However, a significant area of the region, particularly humid and sub-humid zones, is highly infested by the tsetse fly, a vector of trypanosomosis, which affects both livestock and therewith livelihoods (Zaibet et al. 2011). The raising of ERL, such as Ndama cattle, Djallonké sheep and West African Dwarf goats, is seen as a better option to overcome the trypanosomosis problem (Agyemang et al. 1991) because they are well adapted and productive in tsetse-infested areas. Moreover, ERL are tolerant to heat, and resistant/resilient to helminths and tick-borne diseases. Because of their relatively smaller body size compared to Sahelian breeds, they have low nutritional requirements and are generally less demanding in terms of husbandry. Quite often, the ERL breeds are left to graze without herder, particularly in the dry season. In the wet season, they are often tethered away from the crop fields for grazing or (in the case of cattle) are brought together and taken on shortdistance grazing by herders. Livestock breeds in the study sites are predominantly purebred 

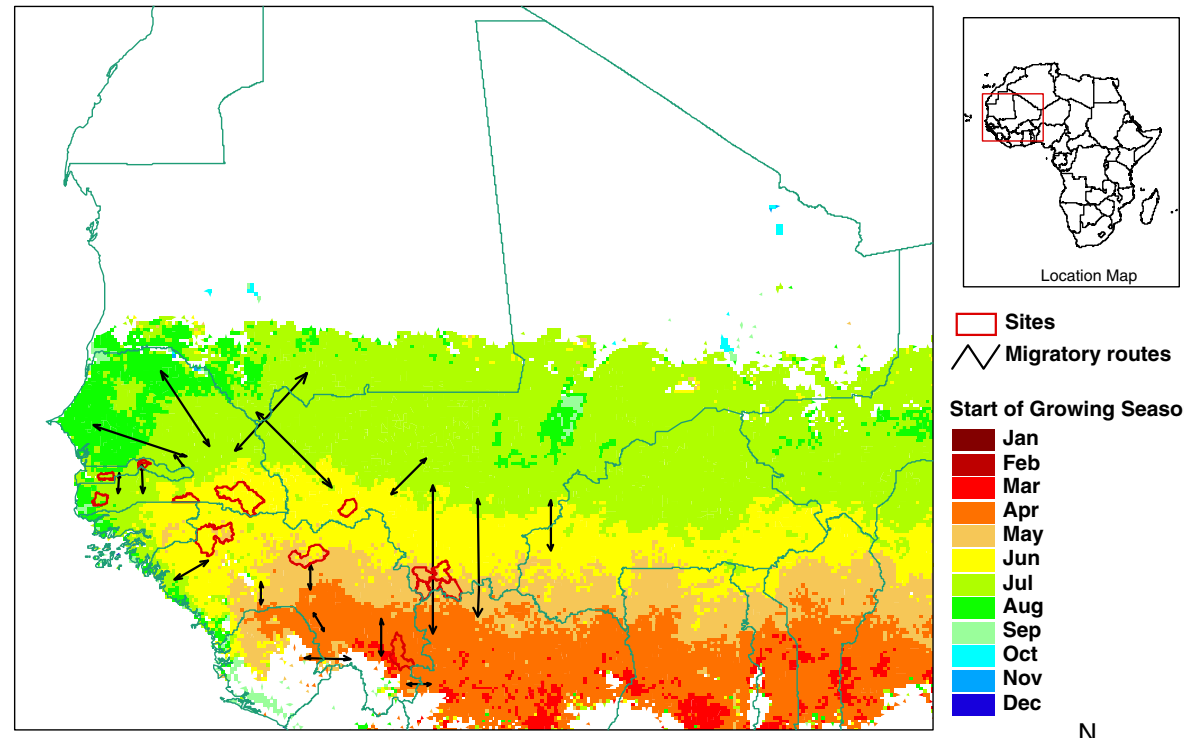

\section{$\square$ Sites $\widehat{\wedge}$ Migratory routes}

Start of Growing Season

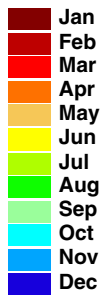

700 0 700 1400 Kilometers

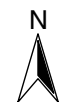

Fig. 3 Map showing the study sites, transhumant routes and start of growing season in Gambia, Guinea, Mali and Senegal
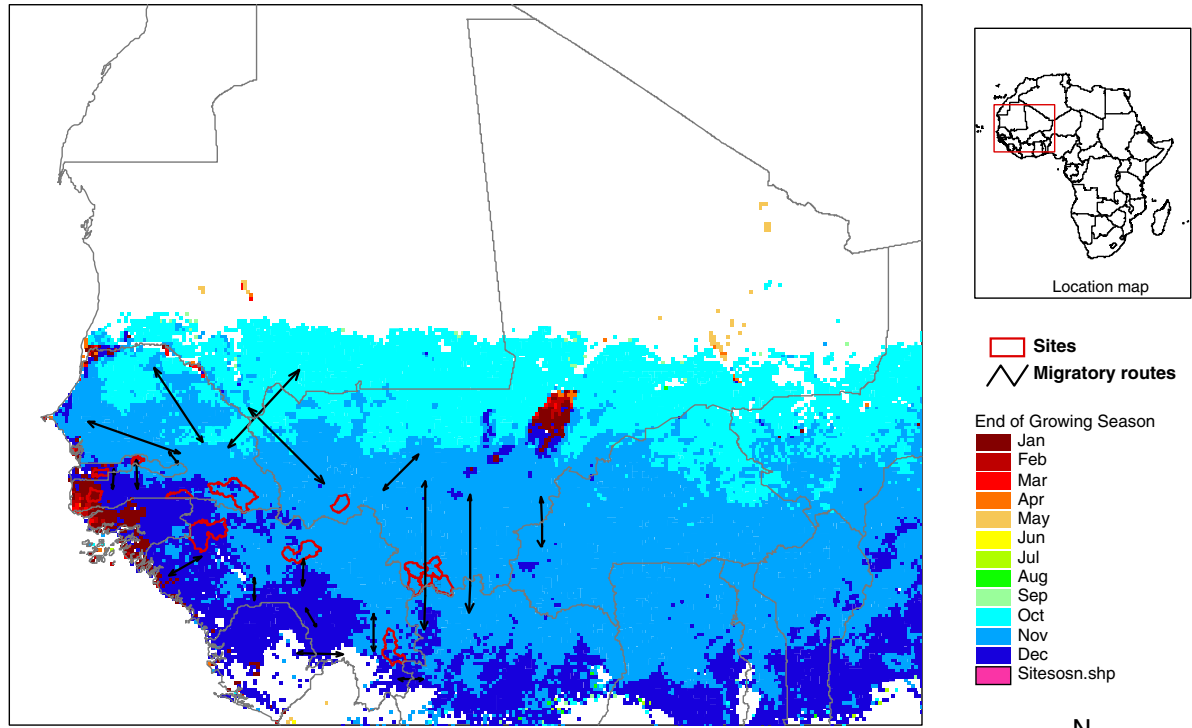

600

0

600

1200 Kilometers

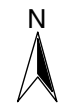

Fig. 4 Map showing the study sites, transhumant routes and end of growing season in Gambia, Guinea, Mali and Senegal 
endemic breeds except for sites in Mali where there is a significant population of crossbred cattle between Ndama and Zebu breeds from the Sahel. In sub-humid zone, livestock population is generally low compared with the Sahelian zone although there is an increasing number of crop farmers owning livestock.

The tsetse fly infestation of the sub-humid zone serves as a natural barrier to the use of abundant pasture resources in the zone by the Zebu cattle and small ruminant breeds from the Sahelian zone. However, with deforestation especially in Southern Mali for cotton production and availability of subsidized trypanocidal drugs, a growing number of pastoralists from the Sahel are moving farther southward to graze pastures in the SudanoGuinean zone. Besides, many pastoralists have settled in the Sudano-Guinean zone of Mali and Cote D'Ivoire to grow crops and raise their livestock, which implies that they have become agro-pastoralists.

\section{Conceptual frameworks underpinning transhumance in West Africa}

The conceptual frameworks underpinning transhumance in West Africa include mobility paradigm, modernization paradigm, stimulus-response concept, migratory drift paradigm and ecological rationality of transhumance. These frameworks help our understanding of socioecological concepts and debates regarding livestock mobility in the region. It has to be emphasized that there is no single conceptual framework that can be used to explain transhumance in West Africa and in the project countries in particular. In this paper, we discuss these paradigms and highlight the issues related to policies and also changes in terms of land use and livestock systems occurring in the pilot sites in the four countries.

\subsection{Mobility paradigm}

The mobility paradigm situates extensive pastoralism through nomadic pastoralism and transhumance as efficient and adaptive use of dryland vegetation and water resources (Moritz 2008). Numerous authors (e.g., Breman and de Wit 1983; Niamir-Fuller 1999; Thebaud and Batterbury 2001; Davies et al. 2010) cite the ecological rationality and sustainability of mobile pastoralism. Proponents of the mobility paradigm call for land use policies that support extensive pastoralism by facilitating livestock mobility, protecting pastures and rangelands from agricultural expansion, and empowering mobile and transhumant pastoralists to manage natural resources sustainably.

A good example of policy that reflects the mobility paradigm is the international agreement among West African countries that allows free cross-border movement of livestock including seasonal cross-border transhumance. The 1998 agreement among the fifteen nations of the Economic Community of West African States-ECOWAS (SWACOECD/ECOWAS 2008) recognizes the ecological and economic logic of mobile pastoralism. It is cited as an exemplary model of socioecologically appropriate policy on livestock mobility in sub-Saharan Africa (Kanyarukiga 2010). The agreement has wideranging impact on cross-border transhumance as well as in integration of regional livestock markets (SWAC-OECD/ECOWAS 2008).

\subsection{Modernization paradigm}

The modernization paradigm posits that agriculture in the Sudanian and Guinean zones is the most viable and ecologically appropriate livelihood strategy (Moritz 2008). Livestock 
rearing is seen as a secondary activity that must be integrated into the agricultural practices of agriculturalists residing in the sub-humid/humid zones. The modernization paradigm views mobile pastoralism and transhumance not so much as anachronistic as much as socioecologically inappropriate: inappropriate because crop farming in the short term will continue to expand across African landscapes at the expense of grazing land before reaching high levels of intensification. Thus through the lens of modernization, there is no room or future for mobile pastoralism or transhumance in Sudanian and Guinean zones. Rather, West African agro-ecological and socioeconomic realities dictate an evolution toward intensification through integrated crop-livestock systems that synergistically intensify both agricultural and sedentary livestock production (Pretty et al. 2011).

An example of the modernization paradigm can be drawn from the conflicting national transhumance policies of Guinea (Balde 2007). These policies are informed by both the mobility and modernization paradigms. On the one hand, there are national and local initiatives to support the country's considerable livestock sector by assuring livestock mobility throughout Guinea. These initiatives can be categorized as actions framed by the mobility paradigm. On the other hand, there are parallel initiatives to modernize Guinean livestock rearing by encouraging more intensive and sedentary livestock rearing. For example, the Programme for the Development of Transhumance (Programme d'Aménagement de la Transhumance) launched in 1991 by the Ministry of Agriculture and Animal Resources (Balde 2007) exemplifies conflicting paradigms at work. The programme embraces the mobility paradigm in its focus of improving the livelihoods of transhumant pastoralists. However, a key goal of the programme over a 10 year period (2007-2018) will be to articulate and operationalize a coherent set of initiatives and policies for modernizing pastoralism in Guinea. A principal strategy for such modernization is to facilitate eventual sedentarization of mobile pastoralists and to "rationalize" or restrict transhumance.

\subsection{Stimulus-response concept (pull-push)}

The stimulus-response conceptualization of mobile pastoralism stems from research on human migration dynamics. A lynch-pin idea of stimulus-response as applied to pastoralism is that critical positive socioeconomic, environmental and sociopolitical factors "pull" transhumant herders toward a particular area and in parallel fashion, critical negative factors such as feed and water scarcity or civil strife, "push" transhumant herders out of a particular area (Basset and Turner 2007; Kratli 2007). The relevance of stimulusresponse concept in explaining livestock mobility depends largely on the production objective of the pastoralists, herd size, household labor availability and livelihood diversification options. Generally, there is low drive for pastoralists with low herd size to be "pulled." The effect of "pull-push" factors on pastoral mobility will also depend on costbenefit of migration.

Livestock diseases and presence or absence of veterinary care can serve as pull-push factors prompting transhumant herders to leave or enter an area. This is especially so in the case of Sahelian livestock breeds that transhumant pastoralists must herd away from areas with trypanosomosis-transmitting tsetse flies. Thus, transhumant herders with Sahelian breeds avoid areas with high tsetse populations and high risk of trypanosomiasis infection. In a parallel fashion, areas in the Sudano-Guinean zone with pasture and water and low risk of trypanosomosis or easy/affordable access to trypanocidal drugs or veterinary care present an opportunity for transhumant pastoralists. An example of this is evident in the Mali-Côte d'Ivoire transhumance axis: readily available trypanocidal drugs and relatively 
accessible veterinary care in Côte d'Ivoire have acted as pull factors prompting transhumant pastoralists to transit through southern Mali for Ivoirian veterinary care opportunities (Basset and Turner 2007).

\subsection{Migratory drift paradigm}

The migratory drift theory of mobile pastoralism builds on stimulus-response conceptualization of mobile pastoralism (Basset and Turner 2007). However, two conceptual innovations distinguish migratory drift from stimulus-response. The first is migratory drift's focus on socioecological and sociopolitical dynamics and the time span required by such processes vis-à-vis human-cum-livestock migration. The second is the theory's attention to human agency as observed in herders' long-term decision making. Migratory drift is a dynamic and long-term process. Its progress may not be evident because its drivers are a complex set of interdependent and mutually reinforcing social, political and agro-ecological factors. Furthermore, the point of denouement for migratory drift is apparent only in retrospect rather than contemporaneously.

An example of migratory drift can be drawn from an historical overview of agricultural and livestock development in southern Mali. Over the past 50 years, global economic factors, national policy and local agricultural technology adoption have interacted in a manner that has facilitated migratory drift and settlement by Sahelian pastoralists in southern Mali. Many of these economic, policy, and technology factors (e.g., promotion of draft power) stem from cotton production in Mali. However, some factors stem from agricultural development and market pull forces in neighboring Côte d'Ivoire (e.g., tsetse control measures and ready access to veterinary services; Basset and Turner 2007). It is this policy environment that has facilitated migratory drift by Sahelian mobile pastoralists into southern Mali and northern Côte d'Ivoire over the past half century. Therefore, the current presence of Sahelian long-distance transhumant herds and herders in this region is not a "sudden invasion." Instead, it is part of a long-term dynamic involving periodic inmigration of transhumant herds and small numbers of transhumant pastoralists settling permanently or temporarily in the southern Mali-northern Côte d'Ivoire area.

\subsection{Ecological rationality of transhumance}

The disequilibria nature of West African ecosystems contextualizes the logic that pastoralists move livestock to cope with and take advantage of the region's climatic variability. Several authors note this logic of "ecological rationality" of transhumance (Breman and de Wit 1983; Thebaud and Batterbury 2001; Adriansen 2008). Adriansen (2008) in exploring local versus scientific knowledge systems for understanding mobility among Peulh herders in Senegal, highlights transhumant pastoralism between the Sahelian and Sudano-Guinean zones as an efficient use of natural resources given the unpredictability and high spatial and temporal variability of West African dryland ecosystems. She notes that though herders may not intentionally consider ecological rationality at the broader landscape level when moving their livestock, they are nonetheless making decisions based on their environmental observations while responding to ecological pull and push factors.

Pastoralists' long-term ecological rationality is evident when viewing transhumance through the analytic lens of migratory drift. Basset and Turner (2007) note that one important factor in Peulh pastoralist migration patterns from Sahelian areas of Niger south to the Sudano-Guinean zone in Mali, and Côte d'Ivoire is the gradual southern shift of isohyets over the past three decades in sub-Saharan Africa. This shift has resulted in a 
southward shift of the ecoclimate zones. That is, the Sahelian zone shifts toward the Sudanian such that northern Sudanian rainfall quantity and patterns resemble quantity and patterns previously observed uniquely in the Sahelian zone. Pastoralists have responded to this gradual isohyet shift along with general increase in drought events by shifting their exploitation of water and pastures farther southward.

\section{Factors, trends and patterns of transhumance in West Africa}

\subsection{Determinant factors of transhumance}

Major factors influencing transhumant pastoralism in the region can be grouped into two broad categories: (1) environmental factors such as climatic change/variability or drought and consequent seasonal pasture and water scarcity, and animal diseases; and (2) socioeconomic factors such as land use changes, demographic pressure, and consequent loss of pastureland, social relations and networks.

Rainfall in the Sahelian and Sudanian zones is unimodal and occurs as one wet (i.e., rain) season spanning 3-4 months. Rainfall in the humid (Guinean) zone is both unimodal and bimodal depending on location. Coastal regions that are closer to the Gulf of Guinea experience bimodal rainfall regimes (i.e., both a short wet season and a long wet season), while more inland northern regions in the Guinean zone experience unimodal rainfall regimes. There is still a fair amount of uncertainty as regards rainfall-related climate projections for West Africa (Thornton et al. 2009). If a simple average of all the model scenarios is taken, slight humidification in the Sahelian region, with no real changes along the Guinean coast can be inferred (IPCC 2007). The impacts of climate change on livestock and agriculture in general in West Africa will vary depending on agro-ecological zones, and the interactions among demographic change, economic development and the environment. The changing frequency of extreme climate conditions such as droughts and floods will have greater impacts on livestock and the associated livelihoods than climate change (that is, average change in precipitation and temperature; Thornton et al. 2009). For example, repeated occurrence of droughts in the Sahel has led to adoption of agro-pastoralism among the pastoralists who were once solely depending on livestock for their livelihood (Turner 2000; SWAC-OECD/ECOWAS 2008). Besides, crop farmers have also diversified in the past two decades into rearing livestock due to repeated crop failure associated with droughts. According to these authors, many farmers own or aspire to own livestock even in many predominantly agricultural areas in West Africa.

Climate changes affect both nomadic and transhumant pastoralists as they have to find new routes to access pastures and water for the livestock. Droughts coupled with demographic changes reduce the amount of forage resources available, forcing herders to take their animals ever further afield. The spatial dynamics of transhumant movement toward the North in the wet season to access pastures and water has been changed by the droughts of 1973/1974 and 1984/1985 in the Sahel (Boutrais 2007). According to this author, Fulani herders in the Dallol Bosso area of Niger who used to move to the North (Mali) in the wet season with their livestock before the drought of 1973/1974 were forced to move southward (Benin and Nigeria) during the drought of 1973 but since then have been going on transhumance to Benin and Nigeria. Besides, the number of transhumant corridors being used by these Peulh herders tends to have increased since the drought of 1973 (Boutrais 2007). Climate change-favorable or not-will alter the quantity and quality of natural pastures and will undoubtedly change the transhumance corridors in the region (Boutrais 
2007). Along with climate change, the expansion of crop fields to marginal lands in many Sahelian countries due to population pressure will further complicate livestock mobility in the region.

Socioeconomic factors influencing transhumant practices stem primarily from demographic pressures in rural West Africa. The overall rate of population growth in the region is nearly $3 \%$ per year (Tiffen 2004). This increase in population is in both urban and rural areas. To keep pace with rising population numbers, rural communities in the region continue to expand agriculture across the region's landscapes. For example, significant agricultural expansion in The Gambia over the past 30 years in the study sites has led to conversion of wetlands and natural vegetation into agricultural cropping fields (ILRI 2010). Agricultural expansion into natural vegetation or into older abandoned fallows often encroaches on areas used as pasture by transhumant herders and local livestock keepers.

Thus, agricultural expansion can act as a push factor prompting herders to leave an area where grazing is constrained by competition with agriculturalists for land. In a complementary fashion, the existence of areas abundant in natural vegetation and free of agriculture can function as a pull factor prompting herders to enter such areas. In the study sites in Mali, demographic pressure has also contributed to deforestation with resultant degradation of ecosystem of ERL and pull of transhumant herds from the Sahel with decline in tsetse challenge. A growing rural population also seems to spur more livestock ownership by agriculturalists (Moritz et al. 2009). A major consequence of more farmer-owned livestock is competition for available feed resources (e.g., crop residues, edible herbaceous species, fodder from trees and shrubs) during the dry season with transhumant pastoralists from the Sahel.

Such resource competition between livestock-rearing agriculturalists and transhumant pastoralists poses significant challenges for community-based natural resource management and land use planning in the Sudano-Guinean zone. Key among these challenges is negotiating resource use and management among the following three social groups that seek control of access to common pool natural resources: (1) first-settler farmers who are an ethnic majority in most of the project sites and have political dominance because their ancestors were first to settle in the area; (2) agro-pastoralists who are often recent immigrants in the community and who may be an ethnic minority or may lack political power because of their immigrant status; and (3) transhumant pastoralists who have legal rights to common pool resources in an area, but who lack political and organizational power because they are not residents of the areas through which they travel while on transhumance.

Social relations and networks with the people at the destination points also influence the mobility patterns of the transhumant pastoralists. In some host communities in the Sudanian and Guinean zones, there are settled pastoralists who often serve as contacts for the transhumant pastoralists. Also, these settled pastoralists in the host communities serve as a valuable source of information to the transhumant herders on pasture and water availability, local conventions and norms governing access to natural resources, and in negotiating access to grazing of crop residues. Absence of this kind of intermediary often leads to communication breakdown between the host-farming community and the transhumant herders, which may trigger conflict.

\subsection{Trends/patterns of transhumant pastoralism}

The trends and patterns of transhumant pastoralism in West Africa in the past 30 years are characterized by the following features: 
1. There have been more southerly movements by transhumant Peulh pastoralists into the Sudano-Guinean zone over the past three decades. This trend has been attributed to severe droughts of the early-1970s and mid-1980s (Basset and Turner 2007). Expansion of cropping into grazing areas in the Sahel has also contributed to southward push of the transhumant pastoralists. In all the 12 sites, we observed increasing expansion of agriculture (ILRI 2010).

2. Long-distance movement from the north (Sahelian zone) to the south (Sudanian and Guinean zone) in dry season in search of pasture and water is still the dominant feature of transhumant pastoralism in West Africa. In the wet season, there is northward movement in the Sahelian zone to graze high-quality pastures and to keep the livestock away from cropping areas.

3. Livestock owners in the Guinean zone, mainly farmers, practice short-distance transhumance in the wet season to avoid damage to crops by the animals. With increasing trend of livestock ownership by the farmers in sub-humid/humid zones, damage to crops by the animals is a growing problem and the best way to avoid this is to keep the livestock away in the wet season.

4. In the past 30 years, some transhumant pastoralists have settled in the Sudanian and Guinean zones to grow crops and raise livestock. Most of the settled pastoralists often have fewer animals and do no longer practice long-distance movement. Some are responsible for management of farmers' livestock in the community (contract herders). Specific examples of transhumant pastoralists who have settled include those from Mali and Burkina Faso who have been gradually settling in the northern Cote d'Ivoire since the droughts of 1970s and 1980s, where they started to grow crops. Same trend has been reported in northern Benin where transhumant pastoralists from Niger and Nigeria have settled and created new villages (SWAC/ OECD 2007).

5. The destination points of transhumant pastoralists are not only determined by availability of pasture and water but also by social relations and networks with the host communities. There are settled pastoralists in some host communities who often serve as contacts for the transhumant herders, and they play a key role in negotiating access to grazing resources, and in resolving conflicts (Basset and Turner 2007).

6. Transhumant routes tend to have increased and are more dispersed in the past 30 years. This has been attributed to increased frequency of droughts and expansion of crop field into livestock corridors, which might have forced transhumant herders to create alternative livestock routes.

7. Increasing number of transhumant pastoralists from the Sahelian countries is taking advantage of growing livestock trade due to rising demands in coastal countries such as Nigeria, Ghana and Cote d'Ivoire (Basset and Turner 2007). Some settled pastoralists in the south have diversified into livestock trade and often serve as intermediary between transhumant pastoralists who want to sell their animals and the buyers.

8. There are more livestock in the Sudano-Guinean zone now than before with increasing livestock ownership by farmers and settlement of some pastoralists in the zone. This trend has exacerbated resource use competition between the indigenous farming population and the transhumant herders and has weakened the long tradition of manure contract whereby transhumant herds were allowed to graze crop residues in order to deposit manure on the crop fields. Competition for scarce grazing resources can lead to conflict. 
9. Though many transit and host communities for transhumant herds in the SudanoGuinean zone have developed local conventions and norms to govern access to pasture and water by transhumant herders in the past 20 years, enforcement has been a major challenge. This can be partly attributed to lack of capacity by the local institutions to enforce the norms and to lack of accountability by the central state officials who often collect illegal taxes/levies from the transhumant herders.

10. Many countries in West Africa have enacted decentralization laws, particularly in the 1990s, with the aim of empowering local communities to manage their resources and ensure downward accountability (Benjamin 2004). One key element of this decentralization reform is delineation of local government (Commune rurale) boundaries and generation of revenue through local taxation. The immediate effect of this on transhumance is multiplication of taxes on livestock herds as they pass through different local government authorities. Besides, local conventions on transhumant herds differ among the communities, and there are communities that are not favorably disposed to the presence of the transhumant herds in their territories even though there are regional and national laws that guarantee freedom of livestock mobility.

\subsection{Livelihood options for transhumant pastoralists}

In view of the increasing resource use competition in the Sudano-Guinean zone due to increase in livestock population, there are three livelihood options available to transhumant pastoralists in coping with the changing contexts. These options are (1) going on transhumance to destination points in other regions of the Guinean zone or more southern regions of the zone. (2) Integrating themselves into local sociopolitical processes by creating ties with local agriculturalists or reinforcing existing social networks with local agropastoralists. (3) Diversifying their livelihood strategies to include other economic activities such as small trade or agriculture. Option 1 entails transhumant pastoralists transiting through farming communities in the Sudano-Guinean zone while en route to more southern points. It may shorten the length of time that individual transhumant herders spend in Sudano-Guinean zones. Option 2 has long been used by transhumant pastoralists. It entails multi-generational networks cultivated over many years with focal points in agro-pastoralists communities throughout West Africa. It also includes cross-ethnic social ties and arrangements with long histories in the region. Option 2 allows individual herders some degree of negotiating local conventions and rules that deal with transhumance. Option 3 entails spreading risks over multiple livelihood strategies, chief among them small-scale agricultural production. Option 3 is a long-term process that entails radical shifts in both livelihood strategy and cultural identity. It can reduce significantly or curtail completely the need for mobility via transhumance for individual transhumant herders. It may also have significant impact on reinforcing social networks.

Trends in transhumance at study sites in southern Mali exhibit Options 1 through 3. For example, Sahelian herders continue to opt for destination points further south in Côte d'Ivoire before the political instability in the country and continue to use communities in southern Mali as major transit points. Integration (Option 2) into local farming communities in southern Mali by some transhumant pastoralists also continues. This is especially so for the Wassoulou region, a cultural region that is centered in Yanfolila administrative district in Mali and extends to northeastern Guinea and northwestern Côte d'Ivoire. Historically, Malinke and Peulh cultures in the Wassoulou region in Mali have blended 
thereby facilitating integration by Peulh transhumant pastoralists from the Sahel into local communities in southern Mali. Diversifying livelihood risks (Option 3) are also observed among the small number of current transhumant pastoralists who opt to settle in the Yanfolila district where one of the study sites (Madina Diassa) in Mali is located. For example, many choose to incorporate some level of small-scale agriculture or small-scale trade and commerce in their livelihood strategies.

Diversification of livelihood strategies is also exhibited by transhumant herders in Senegal near Bandafassi study site (with high rainfall and LGP of 150 days) where herders supply Sahelian breeds of small ruminants for targeted niche markets such as sheep for Tabaski (i.e., the Muslim Feast of Sacrifice celebration or Eid al-Adha). Diversification by pastoralists in the Sahel may also be the origin of a trend of contract herding in the SudanoGuinean zone such that many transhumant herders transiting at or near Mali and Senegal study sites are in fact managing herds, which belong to these Sahelian pastoralists rather than managing their own personal livestock. Sahelian pastoralists who have diversified their livelihood strategies to include small trade and commerce are using contract herders who may be among those who transit at or near Mali and Senegal study sites.

A trend in both Guinea and Mali which impedes transhumant herders from opting for more southern destinations within the Guinean zone (Option 2) are situations of current and recent civil unrest in neighboring countries. Thus in Guinea, the Sierra Leone-Guinea transhumance axe may have been perturbed such that residual transhumant herds remain from the 1990s period of civil unrest in Sierra Leone. Similarly, the Mali-Côte d'Ivoire transhumant axes have been perturbed such that transhumant herders in Mali who in years prior to political instability in Côte d'Ivoire (before 2000) regularly transited through southern Mali for points further south in neighboring Côte d'Ivoire could no longer do so. Instead, transhumant herders use communities in southern Mali as destination points.

\subsection{Transhumant practices in the study sites}

Although many rural communities have stock-roads and transhumance corridors to contain and direct livestock movement toward particular water and grazing resources, the practice of transhumant pastoralism in many communities in the region does not always create physically demarcated trails or permanent routes that can be precisely identified or fully mapped by non-pastoralists. Indeed, the "routes" are often paths that follow a general direction toward specific water and grazing resources. These paths may change over time in response to land use changes (e.g., extension of agricultural cropping fields, reclamation of fallows by farmers, curtailment/establishment of transhumance corridors). However, herders share landscape knowledge with each other on the general opportunities and challenges, terrain, grasslands, agroforestry parklands, fallows, village-cropping fields, forests, local land use politics, etc. that may be encountered en route between specific grazing and watering points. Such knowledge sharing and repeated transhumance trekking across specific areas of the landscape create the "routes," which can be mapped loosely by outsiders.

The main features of transhumant practices in the project sites are presented in Table 1 based on findings from Participatory Rural Appraisal sessions. Generally, transhumant practices tend to be country-specific, and they largely depend on the topography of the site and the dominant livestock production systems. The direction of movements by the transhumant herders in the study sites and countries are presented in Fig. 2. Short-distance, in-country movement of livestock away from cropping areas during the wet season to protect agricultural crops from livestock damage is indeed practiced by all farming and 
agro-pastoral communities at study sites in all four study countries (Table 1). Most of these farmers and agro-pastoralists do not engage in what is considered classic long-distance transhumance because they are either settled agriculturalists who are only recently engaging in livestock rearing and therefore do not own a great number of livestock or they are long-settled agro-pastoralists who have abandoned long-distance transhumance and invest more household labor and resources on crop farming and other livelihood activities than on livestock rearing.

However, agro-pastoralists at two study sites in Guinea were reported to engage in longdistance transhumance. At sites in Gaoual and Dinguiraiye, some communities may be points of departure for long-distance (in-country) transhumance either from the Guinean highlands to the lowlands or from the interior to the Guinean coast. Exceptional cases of long-settled agro-pastoralists who still engage in long-distance cross-border transhumance may also exist at study site communities in Manankoro and Madina Diassa in the administrative districts of Bougouni and Yanfolila, respectively, in Mali. However, significant engagement by recently settled agro-pastoralists or ex-pastoralists in long-distance transhumance in Manankoro, and Madina Diassa may be the rule more than the exception.

The presence of Sahelian breeds of livestock at or near the study sites due to longdistance transhumance originating in West Africa's Sahelian or Sudanian zones is minimal in Senegal and The Gambia, and nonexistent in Guinea. The clear exception is southern Mali. There, several long-term socioecological factors, more current political and economic factors, as well as the transitional nature of agro-pastoralist livelihood strategies contribute to making southern Mali a gateway for Sahelian livestock breeds en route to destinations (e.g., markets) further south in Côte d'Ivoire. To a lesser extent, the Kayes region of Mali may also serve as gateway for Sahelian livestock breeds (mostly small ruminants) en route to destinations west of Senegal.

\section{Transhumant practices and sustainable management of natural resources and endemic ruminant livestock}

\subsection{Perception on impact of transhumance on natural resource management} in the study sites

Transhumant practices affect natural resource management in various ways as presented in Table 2 based on the perception of the stakeholders in the study sites. The stakeholders tended to portray the transhumant practices as generally bad for the management of natural resources in their communities. This negative perception could be explained by the dominance of the ethnic groups who are traditionally farmers and who often do not have a favorable view of the transhumant pastoralists because they are seen as competitors for their natural resources. One major negative view of the transhumance on natural resource management in most of the communities was that it increased the incidence of uncontrolled bush fire which according to the stakeholders interviewed has been on the rise in the past 30 years (ILRI 2010). Uncontrolled bush fire is a major challenge to sustainable natural resource management in all the study sites, and it has direct effect on the ecosystem of the ERL (ILRI 2010). Uncontrolled bush fire destroys not only vegetation but sometimes material properties in the village. The incidence of bush fire is always severe in sub-humid/ humid zones because of heavy vegetation biomass, which implies heavy fire load (ILRI 2010). Other perceived effects of the presence of transhumant herds on the natural resource management in the communities included increased competition for grazing resources due 


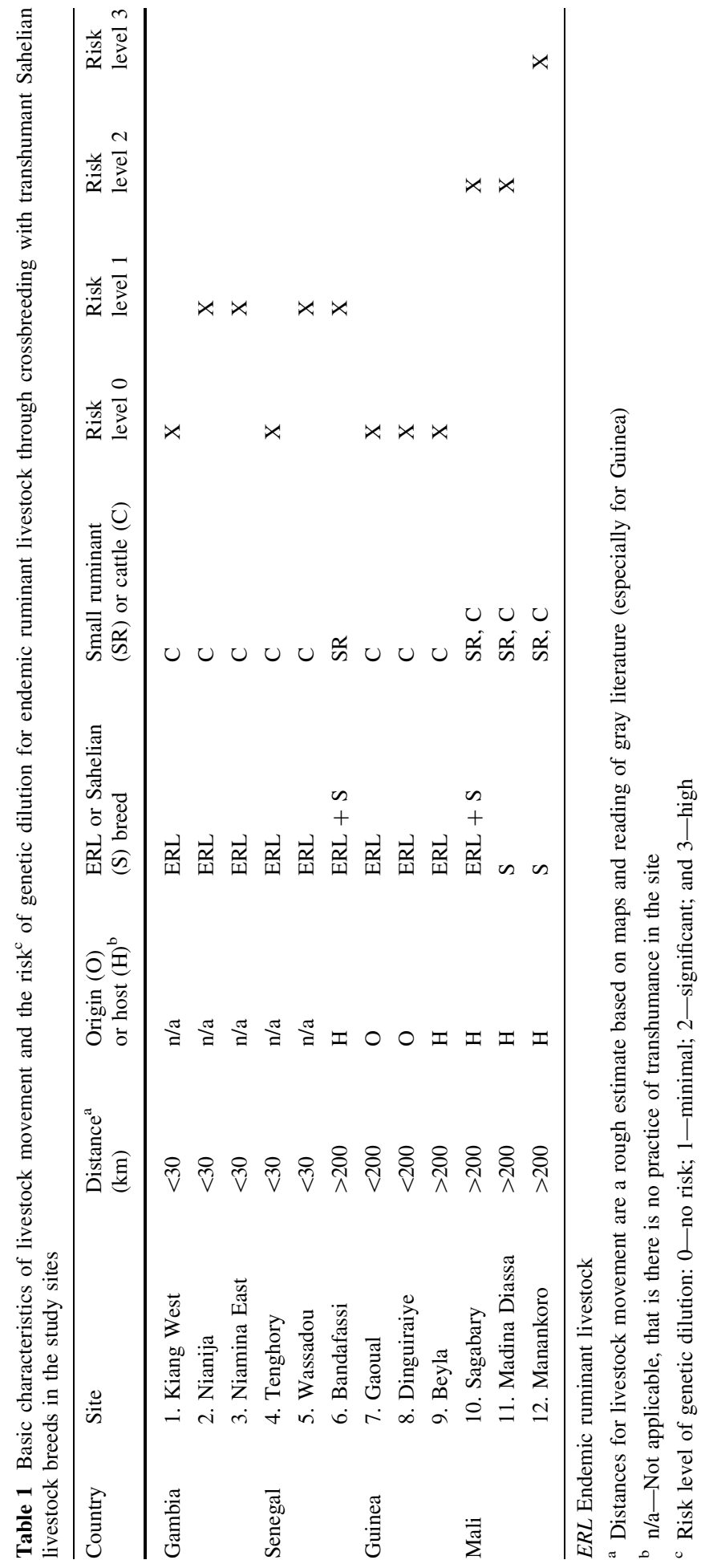


to increased number of livestock, abusive cutting of trees by the pastoralists as feed for their animals, unauthorized grazing of crop residues by the transhumant herds, which often lead to conflict, and spread of invasive species by the transhumant herds. Some stakeholders also mentioned the loss of animals as a major problem associated with the presence of the transhumant pastoralists (Table 2). The explanation for this was that some of the animals of the local people tend to mix up with the transhumant herds and can sometimes follow them when they leave the community.

The only positive view of the presence of transhumance on natural resource management is improvement in soil fertility through the deposition of manure on the field where they graze (SWAC/OECD 2007). In view of generally low application of inorganic fertilizer in the study sites, application of animal manure on crop field is quite common. However, application of animal manure is limited largely by livestock number and sometimes transportation to the crop field to be manured. Hence, the presence of transhumant herds grazing on their crop fields is seen as beneficial by the local populations. In all the sites, the respondents observed that the effect of animal manure on soil fertility often lasts for at least 3 years.

\subsection{Actual and potential impacts of transhumance on ERL in the study sites}

Transhumance may affect in situ conservation of ERL through the presence of Sahelian Zebu breeds in the Malian study sites and sustainable natural resource management for ERL ecosystem conservation through increase resource use competition with the transhumant pastoralists. In an interview of the indigenous population (Bambara farmers), settled pastoralists and transhumant herders in Manankoro, one of the study sites in Mali, at least $60 \%$ of the 54 respondents (29 Bambara farmers, 17 settled pastoralists and 8 transhumant herders) reported a strong competition for grazing resources (Fig. 5). This increased competition for grazing resources, particularly unauthorized grazing of crop residues in the crop field by transhumant herds, was reported by these respondents as one of the major causes of conflict between farmers and herders in this study site.

In terms of sustainable use and in situ ERL conservation, and risk of ERL genetic dilution through crossbreeding with transhumant Sahelian livestock breeds, we classified the study sites in terms of imminent (10-20 years) risk via crossbreeding into four levels (Table 1), based on our study of major transhumance axes in or near study sites, synthesis of available gray and research literature, and preliminary findings from the participatory rural appraisal session. Thus from the above, it is clear that only sites in Mali could be classified as areas where local ERL herds might face significant to high risk of genetic dilution through crossbreeding with transhumant Sahelian livestock breeds in the near term (10-20 years). The high risk of crossbreeding in sites in Mali could be attributed to two main reasons. The first reason is deforestation to cultivate cotton (which is high in the region), which led to reduction in tsetse fly population and disease burden, and the associated pull of the transhumant herders with Sahelian breeds to the sites. The length of the total growing period for cotton is about 150-180 days. All the sites in Mali fall within this period (Fig. 2). The second reason is availability of subsidized trypanocidal drugs that encouraged many community people to crossbreed their endemic Ndama cattle breed with larger frame Sahelian Zebu breeds to meet their need for bigger sized cattle for animal traction.

The risk of crossbreeding with Sahelian livestock breeds is nonexisting in the study sites in Guinea which could be attributed to high tsetse fly population and the associated high disease risk, topography (particularly Beyla and Dinguiraiye which are highlands with 


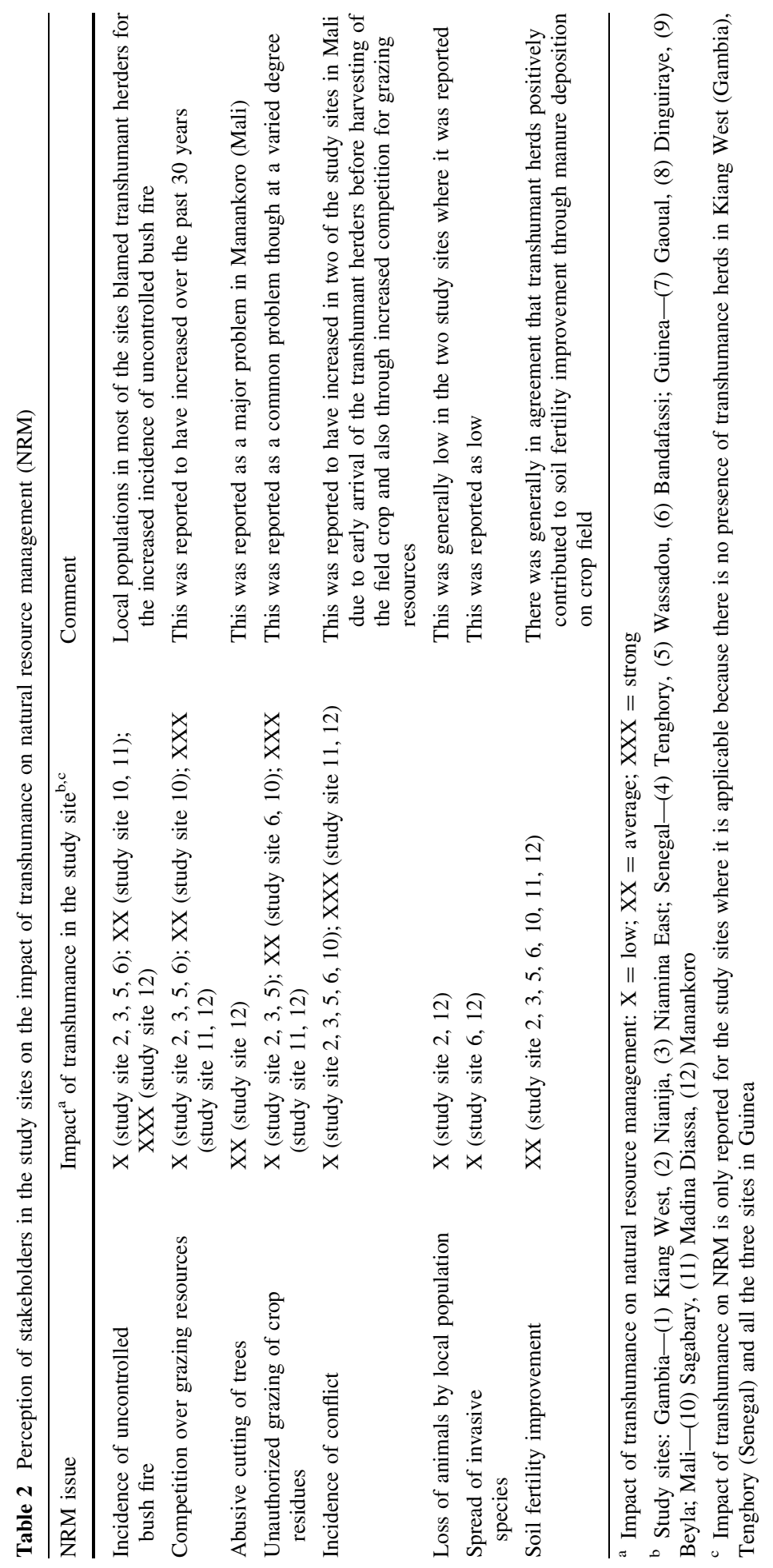




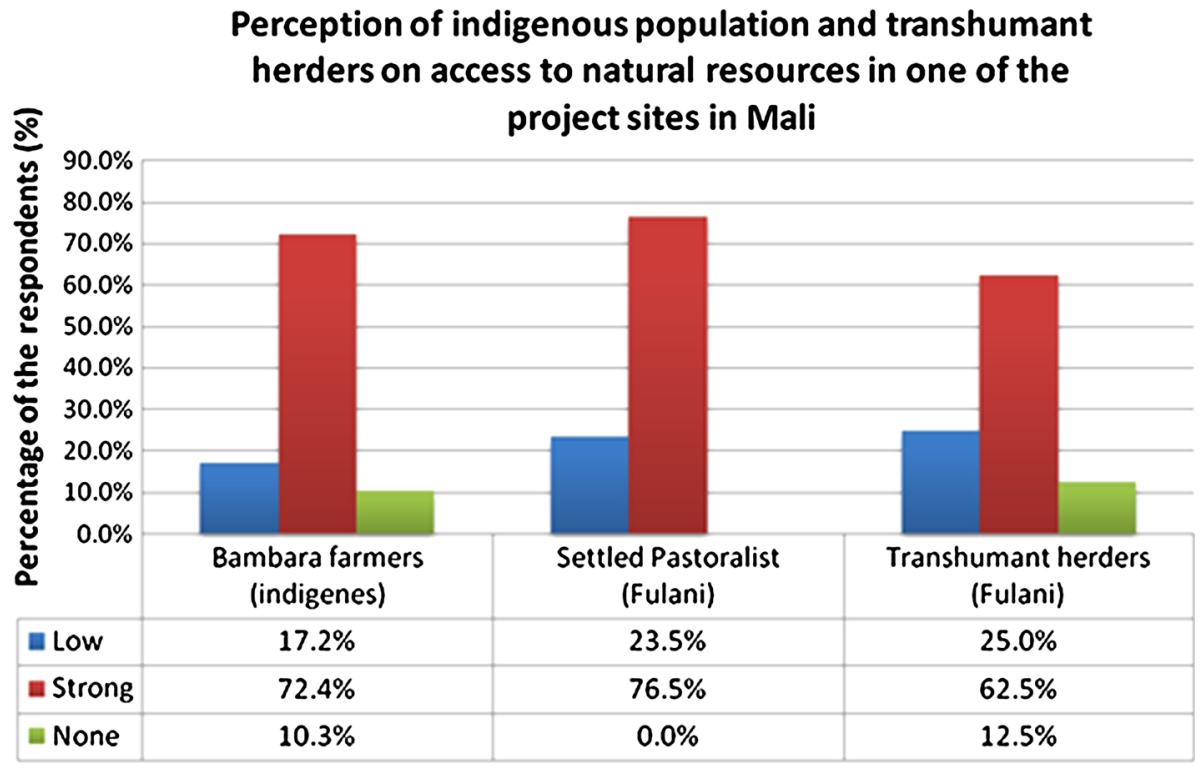

Perception on competition for natural resources

Fig. 5 Perception on access to natural resources in Manankoro, one of the study sites in Mali

elevation of more than 1,500 m), which makes long-distance livestock movement from the Sahelian zone extremely difficult and lack of any other breed besides the endemic livestock in the study sites. For the other sites in Senegal and the Gambia, the general minimal risk is mainly due to high tsetse population and the associated high disease risk for the Sahelian livestock breeds. In addition, the Gambia River and the national boundaries of the Gambia serve to some degree as barriers that prevent influx of Sahelian transhumant livestock. The National Park of Niokolo Koba that borders study site in Bandafassi, Senegal also serves as deterrent to the influx of Sahelian transhumant herds into this site.

\section{Conclusion and recommendations}

From the study, the following policy recommendations regarding transhumance in general and livestock mobility in Sudano-Guinean zone are suggested:

- In addition to legal protection of cross-border mobility of transhumant herds, there is need for better access to information and enhanced communication among all actors involved in transhumance at different levels, and training to ensure all actors are aware of and understand the laws and their provisions.

- There is need for investment in livestock corridors and basic services along the transhumant routes (water points, resting areas, access to markets, clinics, etc.). Developing such routes involves not just financial investments in physical structures (beacons, wells, etc.), but also investment in consensus building and negotiations among all actors to ensure the legitimacy and protection of the routes.

- In addition to regional and national laws and agreements on transhumance, there is need for development of operational guidelines which set out the practical steps and 
modalities for the implementation of these laws/agreements including responsibilities of different actors, sanctions, etc. These guidelines need to be developed with the full collaboration of all actors to ensure their legitimacy. They must also reflect local realities and specificities and must be accessible to all actors. Besides, legal texts and provisions regarding transhumance need to be harmonized in national legislation in all countries in the region.

Acknowledgments This study was carried out under Projet régional de Gestion durable du Bétail ruminant Endémique en Afrique de l'Ouest (PROGEBE), which is a regional project funded by Global Environment Fund (GEF) and African Development Bank (AfDB), and it addresses conservation and sustainable use of endemic ruminant livestock in sub-humid zone of The Gambia, Guinea, Mali and Senegal.

\section{References}

Adriansen, H. (2008). Continuity and change in pastoral livelihoods of Senegalese Fulani. Agriculture and Human Values, 23, 215-229.

Agyemang, K., Dwinger, R. H., Grieve, A. S., \& Bah, M. L. (1991). Milk production characteristics and productivity of N'Dama cattle kept under village management in the Gambia. Journal of Dairy Science, 74, 1599-1608.

Ayantunde, A. A., de Leeuw, J., Turner, M. D., \& Said, M. (2011). Challenges of assessing the sustainability of (agro)pastoral systems. Livestock Science, 139, 30-43.

Balde, H. (2007). Etude sur la Gestion des Parcours dans la Zone de Transhumance du Litoral. Direction Nationale de l'Elevage, Conakry, Guinea. Report.

Basset, T. J., \& Turner, M. D. (2007). Sudden shift or migratory drift? FulBe herd movements to the Sudano-Guinean region of West Africa. Human Ecology, 35, 33-49.

Benjamin, C. E. (2004). Livelihoods and institutional development in the Malian Sahel: A political economy of decentralized natural resource management. PhD Thesis, University of Michigan, USA.

Boutrais, J. (2007). Crises écologiques et mobilités pastorales au Sahel: Les Peuls du Dallol Bosso. Sécheresse, 18(1), 5-12.

Breman, H., \& de Wit, C. T. (1983). Rangeland productivity and exploitation in the Sahel. Science, 221, $1341-1347$.

Davies, J., Niamir-Fuller, M., Kerven, C., \& Bauer, K. (2010). Extensive livestock production in transition: The future of sustainable pastoralism. In H. Steinfeld, H. A. Mooney, F. Schneider, \& L. E. Neville (Eds.), Livestock in a changing landscape. Volume 1: Drivers, consequences, and responses (pp. 285-308). Washington: Island Press.

FAO. (2000). World watch list for domestic animal diversity (3rd ed.). Rome: Food and Agriculture Organization.

FAO. (2001). Pastoralism in the new millennium. Rome: Food and Agriculture Organization, Animal Production and Health Paper 150.

ILRI. (2010). Sustainable management of globally significant endemic ruminant livestock in West Africa (PROGEBE). Gambia Baseline Report. Nairobi, Kenya: International Livestock Research Institute, 95 pp.

IPCC. (2007). Climate change 2007: The fourth assessment synthesis report. Summary for policymakers. Geneva: IPCC. http://www.ipcc.ch/pdf/assessment-report/ar4/syr/ar4_syr_spm.pdf.

Kanyarukiga, S. (2010). Legislation to support cross-border livestock mobility. Common Market for Eastern and Southern Africa-COMESA. Policy Brief Number 14.

Kratli, S. (2007). Cows who choose domestication. Generation and management of domestic animal diversity by WoDaaBe pastoralists (Niger). PhD Thesis, Institute for Development Studies, University of Sussex, England.

Moritz, M. (2008). Competing paradigms in pastoral development? A perspective from the far north of Cameroon. World Development, 36, 2243-2254.

Moritz, M., Kyle, B., Nolan, K., Patrick, S., Shaffer, M., \& Thampy, G. (2009). Too many people and too few livestock in West Africa? An evaluation of Sandford's thesis. Journal of Development Studies, 45, $1113-1133$.

Niamir-Fuller, M. (Ed.). (1999). Managing mobility in African rangelands. London: Intermediate Technology Publications. 
Pretty, J., Toulmin, C., \& Williams, S. (2011). Sustainable intensification in African agriculture. International Journal of Agricultural Sustainability, 9(1), 5-24.

SWAC/OECD. (2007). Promoting and supporting change in transhumant pastoralism in the Sahel and West Africa. Paris: SWAC/OECD. Policy Note Number 3.

SWAC-OECD/ECOWAS. (2008). Livestock and regional market in the Sahel and West Africa-Potentials and challenges. Paris: SWAC-OECD.

Thebaud, B., \& Batterbury, S. (2001). Sahel pastoralists: opportunism, struggle, conflict and negotiation. A case study from eastern Niger. Global Environmental Change, 11, 69-78.

Thornton, P. K., van de Steeg, J., Notenbaert, A., \& Herrero, M. (2009). The impacts of climate change on livestock and livestock systems in developing countries: A review of what we know and what we need to know. Agricultural Systems, 101, 113-127.

Tiffen, M. (2004). Population pressure, migration and urbanization: Impacts on crop-livestock systems development in West Africa. In T. O. Williams, S. A. Tarawali, P. Hiernaux, \& S. Fernandez-Rivera (Eds.), Sustainable crop-livestock production for improved livelihoods and natural resource management in West Africa (pp. 3-27). Nairobi: International Livestock Research Institute and Wageningen: CTA.

Turner, M. D. (2000). Drought, domestic budgeting and wealth distribution in Sahelian households. Development and Change, 31, 1009-1035.

Vrieling, A., de Leeuw, J., \& Said, M. Y. (2013). Length of growing period over Africa: Variability and trends from 30 years of NDVI time series. Remote Sensing, 5, 982-1000.

Winrock International. (1992). Assessment of animal agriculture in sub-Saharan Africa. Arkansas: Winrock International Institute for Agricultural Development.

Zaibet, L., Traore, S., Ayantunde, A., Marshall, K., Johnson, N., \& Siegmund-Schultze, M. (2011). Livelihood strategy in endemic livestock production systems in sub-humid zone of West Africa: Trends, tradeoffs and implications. Environment, Development and Sustainability, 13, 87-105. 